\title{
Mungo McCallum Fairgrieve, M.A.
}

Mungo McCallum Fairgrieve was born at Saltcoats, Ayrshire, on October 30, 1872, and died in Edinburgh on August 4, 1937. He entered Glasgow University in 1890 , and spent five years under Kelvin, of whom he always spoke with affectionate appreciation. In 1895 he proceeded to Cambridge as Scholar of Peterhouse, being classed Senior Optime in 1898 and First Class in the Natural Sciences Tripos in 1899 . For three years he held a teaching post at Eastbourne New College, which, as he used to remark, must have been too much for this school, as it closed down shortly afterwards! In 1903 he joined the staff of The Edinburgh Academy, where that exceptional schoolmaster, the late J. Tudor Cundall, was then raising the standard of science teaching to a level worthy of the school which had nurtured men like Maxwell, J. S. Haldane and D'Arcy Thompson. In 1913 Fairgrieve succeeded Cundall as Head of the Science Department, and in this capacity he remained until compelled to relinquish the post through ill health in 1935. Under his guidance the science buildings grew during the years following the War to an extent which has occasioned a shudder of disgust in more than one Academical laudator temporis acti!

In the limited time which he allowed himself away from his beloved school he was a keen student of meteorology. He published several papers in the Journ. Scot. Meteorol. Soc., of which he was Vice-President, and later, after the Society's amalgamation with the Royal Meteorological Society, Scottish Secretary. At Glasgow he had been a member of the University Mountaineering Club; and afterwards, until his last accident robbed him of the means, he would return constantly to the Cairngorms in search of refreshment of spirit. His regard for his old chief is witnessed by the care with which he prepared one of Cundall's papers for publication (Trans. Chem. Soc., vol. cv, I914, p. 60) and constantly revised the text-books of physics and chemistry used at The Academy.

The last ten years of Mr Fairgrieve's life were shadowed by the effects of two severe accidents. Though crippled by the second he held to his post with uncomplaining tenacity. While always watchful for an opportunity to assist a colleague during a period of ill health, he refused to recognise the fact of his own disablement. He fought a gallant losing battle for several years; so a kindly, stalwart spirit has left us.

He married Miss Helen Gifford, without whose unruffled devotion even his determination must have wavered.

He was elected a Fellow of this Society in I9ro.

W. P. D. W. 